International Journal of Physical Sciences and Engineering
Available online at http://sciencescholar.us/journal/index.php/ijpse
Vol. 2 No. 3, December 2018, pages: $23 \sim 28$
e-ISSN : 2550-6943, p-ISSN : 2550-6951
https://doi.org/10.29332/ijpse.v2n3.182

\title{
Utilization of Atmega328 PIR and Microcontroller Sensors to Improve CCTV Online Performance
}

\author{
I Ketut Sukarasa a , I Gusti Agung Putra Adnyana b, Ita Purnamaimun c, Husnul Hatimah d
}

Article history: Received 2 April 2018, Accepted: 1 September 2018, Published: 14 September 2018

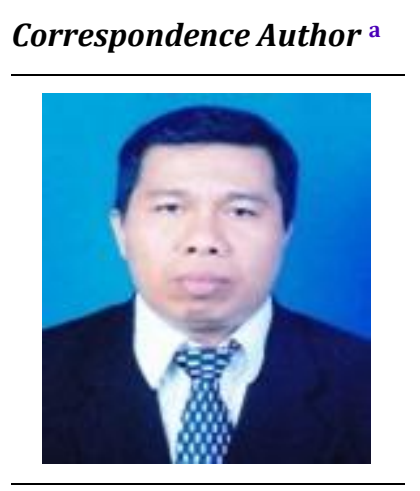

Keywords

ATmega328;

CCTV;

Microcontroller;

PIR;

SIM800L;

\begin{abstract}
A device that can increase security against theft has been made, thus reducing public anxiety to leave their home when the house is empty, especially for a long time. Online CCTV that has been equipped with a PIR sensor, ATmega328 microcontroller, and SIM800L and ISD1820 sound module. The advantages of this system that has been made to have the advantage that not only can be monitored through the monitor screen but can also be seen through a smartphone, another advantage is that the homeowner can prevent theft because the device is equipped with an alarm, if there is movement detected by the PIR sensor in the room, SIM800L will send an SMS that says "There is a movement" to the cell phone number already in the program with the SMS received by the recipient, the homeowner can see whether the movement is a thief or not, if the incoming person is a thief then the SMS recipient can send an SMS reply " on "to turn on the speaker and buzzer. If you want to turn off Buzzer, the homeowner can send an SMS "off".
\end{abstract}

e-ISSN: 2550-6943, p-ISSN: 2550-6951 ๑Copyright 2018. The Author. SS Journals Published by Universidad Técnica de Manabí. This is an open-access article under the CC BY-SA 4.0 license (https://creativecommons.org/licenses/by-sa/4.0/) All rights reserved.

\section{Contents}

Abstract

1. Introduction

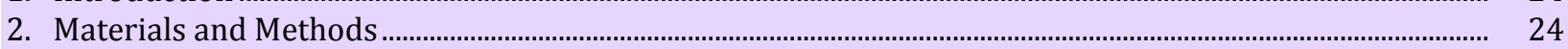

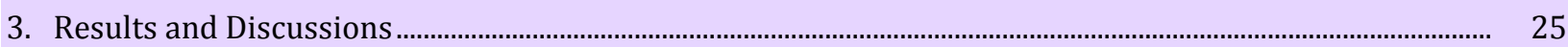

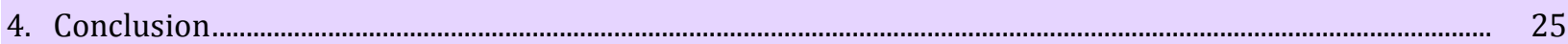

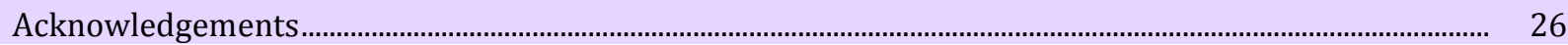

a Department of Physics, University of Udayana at Bali, Indonesia

b Department of Physics, University of Udayana at Bali, Indonesia

c Department of Physics, University of Udayana at Bali, Indonesia

d Department of Physics, University of Udayana at Bali, Indonesia 


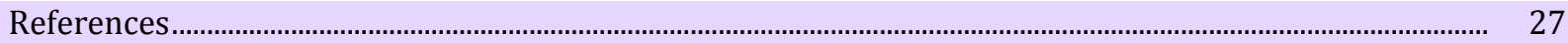

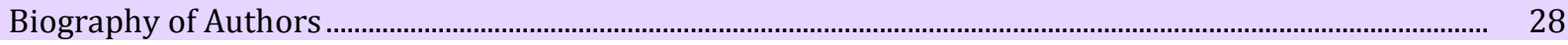

\section{Introduction}

Many methods have been carried out to improve security against theft including Design and Development of a Versatile and Intelligent Home Security System (Md. Khalid Hossain Jewel, 2017), this system only uses the camera to capture images without giving information whether the moving is a thief or not. Real-Time Security System using Human Motion Detection (Ahire Upasana, 2017), this system uses CCTV motion detection which utilizes the ability of motion detection sensors that exist on CCTV where if the signal is activated the CCTV will be active and CCTV will record images of the computer and the computer will send an SMS according to the telephone number stored in the database. Embedded Home Surveillance System with Pyroelectric Infrared Sensor Using GSM (Rupali R. Ragade, 2017), this system uses PIR sensors and ultrasonic sensors to detect temperature changes and motion detection, if there is movement and temperature changes, the microcontroller will activate the alarm and send an SMS to the number stored in the database. Judging from the security system that has been made, there is still a weakness that occurs that real information that occurs in a controlled room cannot be seen properly, such as whether it is indeed true that in the controlled room is someone who should not enter a controlled room.

In this system, it has the advantage that not only can be monitored through the monitor screen but can also be seen through a smartphone, if the information received is true that the person who is not supposed to enter the controlled room the SMS recipient can type "on" to activate the alarm and buzzer (Bento: 2018).

\section{Materials and Methods}

This research was carried out in the Laboratory of Electronics and Instrumentation of the Department of Physics, Faculty of Mathematics and Natural Sciences, Udayana University. The study began by designing a schematic circuit. After a schematic linking, the component compilation is carried out as shown in Figure 1.

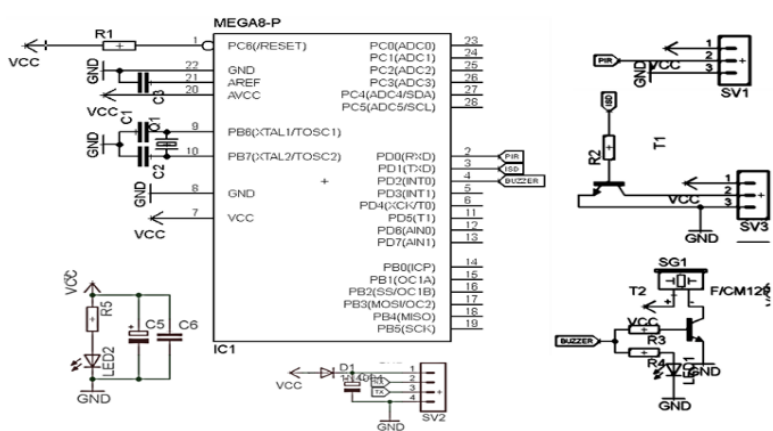

Figure 1. Schematic circuit design tool

The schematic circuit design tool consists of a minimum ATmega328 microcontroller system, a PIR sensor as an input device, buzzer, and speaker as an output device controlled by ISD1820. Input devices are sensors which are the source of commands for the microcontroller (Bento: 2018). Normal conditions PIR sensor logic 0 , if the sensor detects the movement of the object then the PIR sensor is logic 1 . If the sensor logic 1 , the command will be processed in the ATmega328 microcontroller then send an SMS to the mobile phone with the help of SIM800L (Rimawan, et al.: 2018). 


\section{Results and Discussions}

The tool design results obtained from this study are as shown in Figure 2. The use of PIR sensors and ATmega328 microcontrollers to improve online CCTV work. The PIR sensor will only issue logic 0 and 1 , logic 0 will occur when the sensor does not detect any changes in motion and logic 1 when the sensor detects a change of movement.

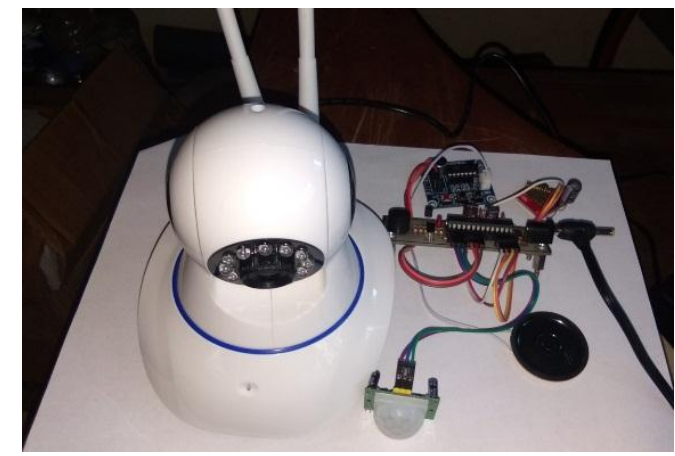

Figure 2. Tool design using PIR sensor and ATmega328 microcontroller to improve online CCTV work

If the PIR sensor detects movement, the ATmega328 microcontroller will execute the program and SIM800L will send a message to the cell phone in the form of text that says "there is movement". If from the mobile phone sends a reply to the text in the form of a text message that says "on" then the speaker from isd will sound according to the previous recorded followed by a buzzer, then there will be a message into the mobile in the form of text that reads "buzzer on". Furthermore, if from the mobile phone sends a reply to the text in the form of a text message that says "off" then the buzzer which initially sounds will stop ringing, then there will be a message entering the cellphone in the form of text that reads "dead buzzer". The text display on the cell phone is shown in Figure 3.

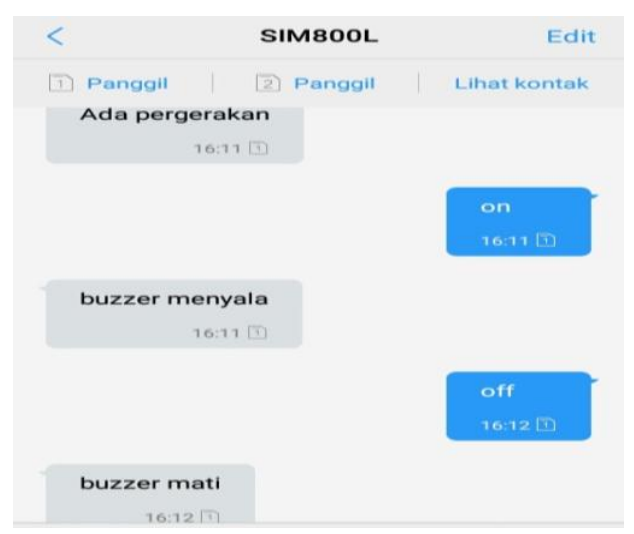

Figure 3. Display text on mobile

\section{Conclusion}

The information system for the presence or absence of people in a closed room is the entry of text to the mobile phone with the telephone number that has been in the previous program. The command used to send SMS from the mobile to the SIM800L module all uses lowercase letters. The commands that have been sent to the SIM800L module will get a reply according to the program that has been created. Suppose if the command "on" is sent then the buzzer and speaker will sound and will get a reply "buzzer sounds". Likewise, the "off"

Sukarasa, I. K., Adnyana, I. G. A. P., Purnamaimun, I., \& Hatimah, H. (2018). Utilization of atmega328 PIR and microcontroller sensors to improve CCTV online performance. International Journal of Physical Sciences and Engineering, 2(3), 23-28. https://doi.org/10.29332/ijpse.v2n3.182 
command will get a reply "buzzer and speaker off". In the tool made in this study, the reply to the SMS received from the tool sometimes takes a long time and sometimes does not respond to the commands given. The occurrence of these problems usually occurs because the signal is not good. It is necessary to examine the speed of the PIR sensor's sensitivity response to detect changes in movement with different distances and angles.

\section{Acknowledgments}

Praise God, the writer offered the Presence of God Almighty because of His blessings and blessings the writer could complete this paper. On this occasion, we also did not forget to thank: Udayana University Chancellor as the fund holder, Udayana University Institute of Research and Community Service (LPPM) who provided the opportunity to carry out research, Dean of the Faculty of Mathematics and Natural Sciences, Udayana University, Physics Study Program, University Mathematics Faculty Udayana and Friends of the Physics Study Program Lecturer at Udayana University. 


\section{References}

Bento, A. C. (2018). Internet of Things: An Experiment with Residential Automation for Robotics Classes. International Research Journal of Management, IT and Social Sciences (IRJMIS), 5(2), 113-119.

Bento, A. C. (2018). IoT of Nextion X TFT ILI9341: Experimental Results and Comparative Survey. International Research Journal of Engineering, IT and Scientific Research (IRJEIS), 4(2), 14-23.

Jewel, M. K. H., Mostakim, M. N., Rahman, M. K., Ali, M. S., Hossain, S. D., Hossain, M. K., \& Ghosh, H. K. (2017). Design and Development of a Versatile and Intelligent Home Security System.

Ragade, R. R. (2017, October). Embedded home surveillance system with pyroelectric infrared sensor using GSM. In Intelligent Systems and Information Management (ICISIM), 2017 1st International Conference on (pp. 321 324). IEEE.

Rimawan, I. G. A., Supardi, I. W., \& Astawa, I. P. A. (2018). Meat water content meter using copper electrode sensor based on AT89S52 microcontroller. International Research Journal of Engineering, IT and Scientific Research, 4(5), 1-6.

Upasana, A., Manisha, B., Mohini, G., \& Pradnya, K. (2014). Real Time Security System using Human Motion Detection. In International Conference on IEEE.

Sukarasa, I. K., Adnyana, I. G. A. P., Purnamaimun, I., \& Hatimah, H. (2018). Utilization of atmega328 PIR and microcontroller sensors to improve CCTV online performance. International Journal of Physical Sciences and Engineering, 2(3), 23-28. https://doi.org/10.29332/ijpse.v2n3.182 


\section{Biography of Authors}

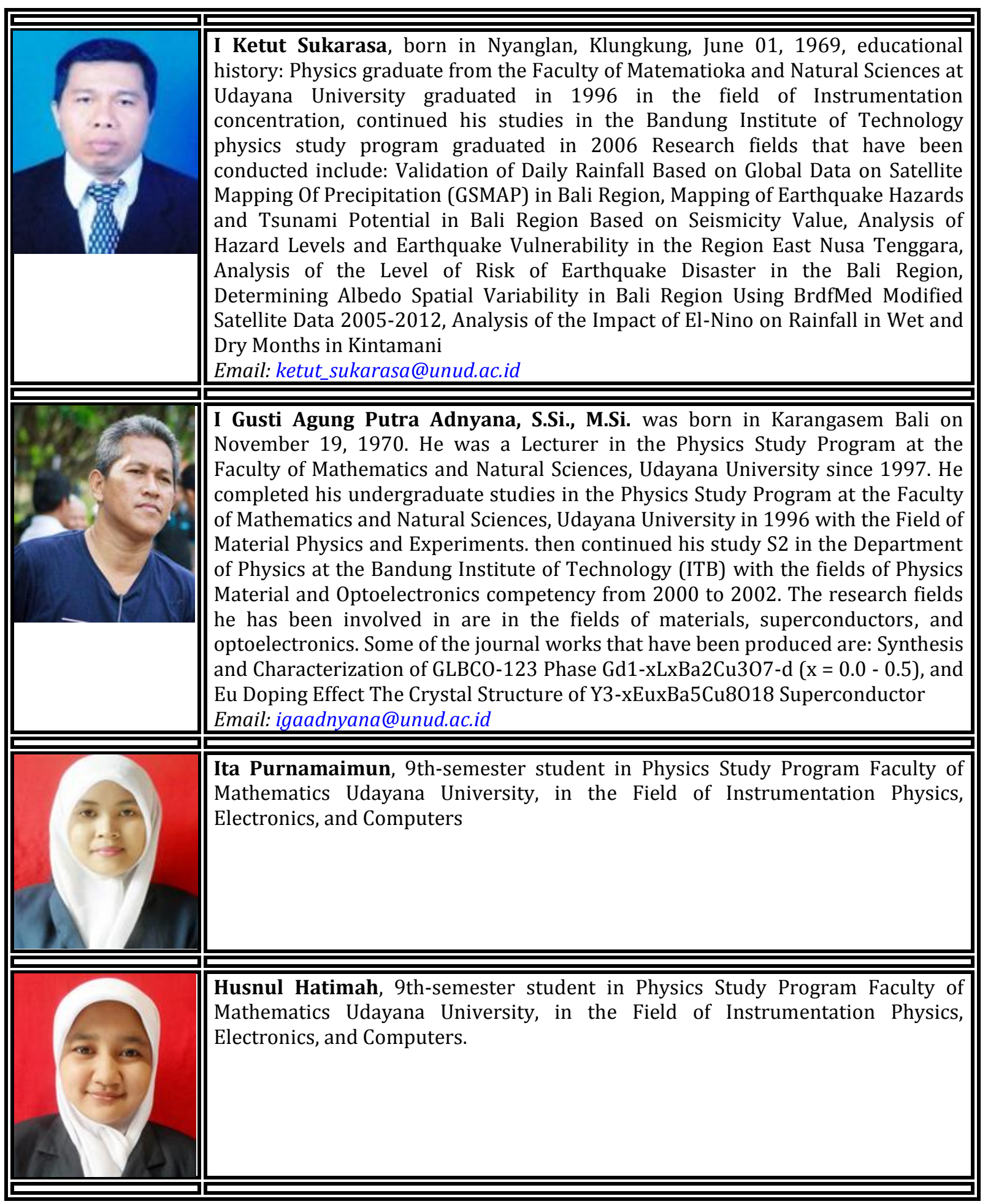

